American Journal of Environmental Sciences 7 (1): 20-25, 2011

ISSN 1553-345X

(C) 2010 Science Publications

\title{
Impacts on International Migration and Remittances Growth
}

\author{
${ }^{1}$ Ferdous Alam, ${ }^{1}$ Chamhuri Siwar, ${ }^{2}$ Basri TaliIb and ${ }^{1}$ Rabiul Islam \\ ${ }^{1}$ Institute for Environment and Development, \\ ${ }^{2}$ Department of Economics, Faculty of Economics and Business, \\ University Kebangsaan Malaysia, 43600 UKM, Bangi, \\ Darul Ehsan, Selangor, Malaysia
}

\begin{abstract}
Problem statement: This study provided a brief discussion of the international migration, an age old common phenomenon is an emerging economic development issue and remittances growth. Approach: Each year Bangladesh exports huge number of labours abroad for foreign currency, called remittance. In the last four decades remittances played a major role to eradicate the poverty level in Bangladesh and it has experienced positive economic changes in Bangladesh. Now a day's migration has been a common livelihood strategy of Bangladeshi people. Results: It contributed for the development of both sending and receiving countries as well as contributed at family level and community level. At family level, migration may improve household earnings, food, health, housing and educational standards. At the community level, improvement could be noticed in health, education, sanitation and infrastructure benefiting both migrants and non-migrant households. Conclusion: The aim of this study was to highlight and clarify the impacts on international migration and remittances growth in Bangladesh.
\end{abstract}

Key words: Remittance growth, Foreign Direct Investment (FDI), New Economics of Labour Migration (NELM), international migration, economic development, financial stability, recipient countries, Bureau of Manpower, Employment and Training (BMET), global circulation

\section{INTRODUCTION}

International Migration refers to the cross-border movement of people from a mother country to a location outside that mother country, with the purpose of taking up higher income employment, better living conditions, higher education get access to civic amenities and conducting a daily existence there for an extended period of time. According to the social scientists, it has a tremendous potential for human progress, global circulation and integration by the human mobility (Castles and Wise, 2008). It can have significant positive impacts on household well-being and economic growth through improved income opportunities, knowledge transfers and increased integration in the global economy (The World Bank, 2005). Since the mid 1970s, international labour migration has become an important element of survival for many households in Bangladesh. Migration carries both high costs and risks for migrants and their families who lose an important member of the household for an extended period of time yet every year thousands of
Bangladeshis migrate to the Middle East and other developed countries of the world Europe, North America, Australia and Asia especially Malaysia for employment.

Bangladesh export migrant workers to 13 Middle Eastern and North African counties. Only 8 countries among them, account for more than $82 \%(24,10,690)$ of the total migrants till now. This flow has been particularly high in the last two years, according to the Bangladesh Bureau of Manpower, Employment and Training (BMET), 381,516 people left the country in 2006, an increase of 50\% over the previous year 2005 and this number has $60 \%$ increased in 2007. The formal 'export of manpower" was launched in 1976 with the number at 6,087 workers only. In 2005 the export went up to 252702. Form 1976 to April 2006 altogether 4273000 people has migrated from Bangladesh on overseas employment (Internal Resources Division, 2005).

Eighty two percent world's migrants come from developing countries; Bangladesh, China, India, Mexico, Russia and Ukraine are the top migrant sender countries (The World Bank, 2005). The share of

Corresponding Author: Ferdous Alam, Institute for Environment and Development, University Kebangsaan Malaysia, 43600 UKM, Bangi, Darul Ehsan, Selangor, Malaysia 
remittances in household income has risen from 3.7\% in 1987-88-18.5\% in 2000; meanwhile, the total volume of remittances has been growing at a pace of $20 \%$ per annum and is likely to exceed a total of US\$ 6 billion in 2007 (IMF, 2005). The amount of remittances in terms of GDP $7.7 \%$, exports $45.6 \%$ and imports $32.6 \%$ in 2006 (Ministry of Finance, 2003). According to the BMET (Bureau of Manpower, Employment and Training) in 2009 the earning of the remittances was USD \$10720.20 million and total earning remittances from 1974 up to 2009 was USD \$67676.58 million, beside of this another $40 \%$ will be addition for the unofficially. Given its size, the stability of remittances inflow has become an important issue due to its growing development potentials to affect both micro and macro economy via current account financing and influencing liquidity of the banking system. Various kinds of migration, particularly income-seeking migration across national boundaries, have attracted much attention in the recent scholarly and policy literature (Morawska, 2001).

In worldwide terms, the large amount of remittances sent back by migrant workers has spurred an intense debate on their potential effects for poverty reduction, financial stability and economic development of migrant sending countries (Ratha, 2003; The World Bank, 2005; Maimbo and Ratha, 2005). A significant number of labor migrants residing in northern European countries has, over the years, returned their savings as remittances to their country of origin either as a supplementary source of income to family and relatives or to start new businesses in their country of origin while, on the other hand, some other migrants are trying to raise loan capital to start new businesses in their country of residence (Shahamak, 2010). Remittances are more than doubled over the 1990s from the developing countries, whereas official aid flows showed a declining trend. Remittances have proved to be less volatile, less procyclical and therefore a more reliable source of income than other capital flows to developing countries, such as Foreign Direct Investment (FDI) and development aid (Gammeltoft, 2002; Keely and Tran, 1989; Puri and Ritzema, 1999; Ratha, 2003). Remittances affect poverty eradication most directly by increasing the income of households which have a family member working abroad. Because income from remittances is usually larger than that which could have been earned by migrants they stayed at home. The impacts of migrant remittances touch not just the macro economic factors and the dependents of the migrants in home countries. They influence the social structure in terms of life standards, rural financial and trade activities and income consumption levels of the people of particular community/villages both actively and passively. Many recipient families get rid of extreme poverty situation, at least marginally.

The purpose of this study is to obtain the consequences of irregular migration and its effects on sustainable migration and the impacts on international migration and remittances growth in Bangladesh.

\section{MATERIALS AND METHODS}

Data attainment: The study is conducted in University Kebangsaan Malaysia, Bangi since July, 2009 to November, 2010. The data for analysis is perceived from secondary sources in Bangladesh. The significant manipulations for acquired data are international migration and remittances growth. The corresponding outcomes are demonstrated from the analysis of collected data.

International migration: International migration happened when peoples cross the boundaries of native country and stay in another host country for several duration of time (Stanat and Christensen, 2006). Migration happened for many reasons. Most of the people leave their native countries for economic opportunities in another country. Others migrate with their family members which have migrated intended for political conditions in their countries. Another reason for international migration is education; pursue their studies in abroad as students (OECD, 2007). There are several possible systems for a label of international migrants, one system categorizes them into nine groups: temporary labour migrants; illegal, or undocumented migrants; highly skilled and business migrants; forced migration; irregular migrants; asylum seekers; family members; refugees; return migrants; and long-term, lowskilled migrants (Stanat and Christensen, 2006). These migrants can be separated into two large groups, permanent and temporary migrants. Permanent intend to establish their residence in a new country for permanently and possibly achieve for this country's citizenship. Temporary migrants intend only to reside for a limited duration of time; perhaps until the finish of a particular program of study or for the duration of their work contract or a certain work period (OECD, 2007). The economies and societies are significantly affected on the host country and the native country by the both kinds of migrants. Likewise, the countries which receive these migrants are often grouped into four classes: European countries which encouraged labour migration after II World War, European countries which receive a major portion of their immigrant populations from their former colonies, traditional settlement countries and countries which previously were points of emigration but have 
Am. J. Environ. Sci., 7 (1): 20-25, 2011

recently emerged as immigrant destinations (Stanat and Christensen, 2006).

The New Economics of Labour Migration (NELM) defines the international migration as an instrument that households use to conquer market failures. A household makes an investment by sending a family member to work abroad, which is recovered when the migrant's get there remittances. These remittances compensate credit, weakly functioning local markets for capital or for absent and futures. Who leaves a place for any permanent change in residence is migration and an immigrant is a new-fangled arrival. Move between two countries is an international migration. If the immigrant follows the new country's legal procedures for permanent arrivals is legal migration. An alien is a citizen of one country but living in another country; temporary aliens are visitors. Refugees who are unable or unwilling to return home because of fear of harassment.

Adams Jr. and Page (2003) had studied the impact of international migration and remittances on poverty in developing world. In this study, they used the crosscountry data to analyze how international migration and remittances affect poverty in the developing world and basic growth poverty model suggested by Ravallion and Chen (1997). This study based on data set on international migration, remittances, inequality and poverty from 71 developing countries. The results show that both international migration and remittances significantly reduce the depth, severity and level of poverty in developing world. After an instrument for the possible endogeneity of international migration and controlling for various factors, results suggest that, on average, a $10 \%$ increase in the share of international migrants in a country's population will lead to a $2.1 \%$ decline in the share of people living on less than $\$ 1$ per person per day. After an instrument for the possible endogeneity of international remittances, a similar $10 \%$ increase in per capita official remittances will lead to a $3.5 \%$ decline in the share of people living in poverty. Although the available evidence in still relatively limited, growing evidence from household survey data complements the findings of the model that international remittance has to reduce the incidence and severity of poverty in several low income countries. According to that evidence remittances are believed to have reduced the poverty headcount ratio by $11 \%$ points in Uganda, 6\% points in Bangladesh and 5\% points in Ghana (Richard, 2006).

The factors driving migration are thus part of the broad processes of social transformation that have affected the societies of Africa, Asia and Latin America, as they have been drawn into the world economic and political system created by the cultural and technological domination of Western Europe and North America since the 16th century (Castles, 2007).
Remittance: Transfer of money by a foreign worker to his or her home country is called remittance. Money sent back to home by migrants in many developing countries constitutes the second largest monetary inflow, exceeding worldwide aid. Estimates of remittances to developing countries vary from International Fund for Agricultural Development's US\$301 billion (including informal flows) to the World Bank’s US\$250 billion for 2006 (excluding informal flows). Remittances contribute to economic development and to the livelihoods of global people. Remittance transfers can also support access to financial services for the sender and recipient, thereby increasing financial and social inclusion. Remittances also promote, in the receiving countries, a further economic dependence on the global economy instead of building sustainable, local financial system. It can be concluded that impact of international labour migration and remittances on poverty reduction is positive.

The economies in many countries are playing an increasingly large role by the remittances, contributing to economic growth and to the livelihoods of developing people. As remittance receivers often have a higher propensity to own a bank account, remittances support access to financial services for the sender as well as recipient, an essential aspect of leveraging remittances to uphold economic development. The top recipients of remittances in GDP included many less significant economies such as Tajikistan (45\%), Moldova (38\%) and Honduras (25\%). The World Bank and the Bank for International Settlements have developed international standards for remittance services. During disasters or emergencies, remittances can be a vital source of income. According to the Overseas Development Institute, remittances is being increasingly recognized as important by aid actors who are considering better ways of supporting people in emergency responses (Harvey, 2007). The top remittances recipient countries are shown in Table 1 from 2006-2010. India was the highest remittances recipient country. The remittances of India recipient received $\$ 26.9$ billion in 2006, $\$ 27$ billion in 2007, $\$ 45$ billion in 2008, $\$ 55.1$ billion in 2009 and the estimated $\$ 55$ billion in 2010 and the remittances of Bangladesh recipient $\$ 5.5$ billion in 2006, $\$ 6.6$ billion in 2007, \$9 billion in 2008, \$10.7 billion in 2009 and the estimated \$11.1 billion in 2010.

The impact of remittance transfers on the developing economies countries are only beginning to be established. Remittance transfers have been present for centuries, but have only earned the attention of economists and international financial institutions within the last two decades. The reasons for this failure to notice include both the relatively small amounts of money sent with each transfer and the often-marginal social status of both the sender and the receiver. It also assesses the positive and negative impacts that remittances may have on developing and development economies. 
Am. J. Environ. Sci., 7 (1): 20-25, 2011

Table 1: Top remittances recipient countries

\begin{tabular}{|c|c|c|c|c|c|}
\hline \multirow[b]{2}{*}{ Country } & \multicolumn{5}{|c|}{ Remittances (billion USD) } \\
\hline & 2006 & 2007 & 2008 & 2009 & $2010 \mathrm{e}$ \\
\hline India & 26.9 & 27.0 & 45.0 & 55.1 & 55.0 \\
\hline Mexico & 25.6 & 26.1 & 25.1 & 21.2 & 22.6 \\
\hline Philippines & 12.7 & 14.4 & 16.4 & 17.3 & 21.3 \\
\hline Bangladesh & 5.5 & 6.6 & 9.0 & 10.7 & 11.1 \\
\hline Pakistan & 5.1 & 6.0 & 7.0 & 8.7 & 9.4 \\
\hline Morocco & 5.1 & 5.7 & 6.9 & 8.0 & 6.4 \\
\hline China & 22.5 & 25.7 & 40.5 & n.a. & 51.0 \\
\hline Poland & 8.5 & 12.5 & 13.8 & n.a. & 9.1 \\
\hline
\end{tabular}

Source: World Bank (2010)

Remittances have various functions and roles for example Azad (2005) suggested using remittances for the development of micro-enterprises. Focuses on structural changes of remittances in Bangladesh. Empirically examines the macroeconomic determinants of remittances inflows in Bangladesh. Bangladesh has potentials to tap into huge amount of remittances. Immense potentialities of remittance inflow in Bangladesh. Nasiruddin and Das (2007) cite some policy options to promote remittances inflows in Bangladesh.

\section{RESULTS AND DISCUSSION}

The migrant employment and remittances has been discussed in this study. Table 2 demonstrate the migrant employment of Bangladesh 1990, 2000 and 2008. The largest migrant employment of Bangladesh is 57486 in 1990, 144618 in 2000 and 132124 in 2008. The largest migrant employment of Bangladesh increased 26.6\% per year from 1990 to 2000 in Singapore and increased 36.0\% per year from 2000 to 2008 in Qatar. Bangladeshi employment engaged in the world and Malaysia show in the Table 3. The total Bangladeshi employment engaged 103814 in the world in 1990 and 1385 in Malaysia (1.3\%) of the total employment in 1990 and the total Bangladeshi employment engaged 875055 in the world in 2008 and 131762 in Malaysia (15.1\%) of the total employment in 2008. The total employment of Bangladesh engaged 6265909 in the world and 686270 in Malaysia $(11.0 \%)$ of the total migrant employment from 1990-2008. The total employment and remittances of Bangladesh for 1990-2008 was presented in Fig. 1. The figure showed that the total migrant employment and remittances of Bangladesh gradually increased from 1990-2008. The total migrant employment of Bangladesh was 103814 in 1990 and 875055 in 2008 and the total remittances of Bangladesh were \$781.54 million in 1990 and \$9019.60 million in 2008.
Table 2: Migrant employment of Bangladesh

\begin{tabular}{|c|c|c|c|c|c|}
\hline \multirow[b]{2}{*}{ Country } & \multirow[b]{2}{*}{1990} & \multirow[b]{2}{*}{2000} & \multirow[b]{2}{*}{2008} & \multicolumn{2}{|c|}{$\begin{array}{l}\text { Average annual rate } \\
\text { of change }\left(\% \text { year }^{-1}\right)\end{array}$} \\
\hline & & & & $1990-2000$ & $2000-2008$ \\
\hline Saudi Arab & 57486 & 144618 & 132124 & 9.2 & -1.1 \\
\hline U.A.E. & 8307 & 34034 & 419355 & 14.1 & 31.4 \\
\hline Kuwait & 5957 & 594 & 319 & -23.1 & -7.8 \\
\hline Oman & 13980 & 5258 & 52896 & -9.8 & 28.9 \\
\hline Qatar & 7672 & 1433 & 25548 & -16.8 & 36.0 \\
\hline Bahrain & 4563 & 4637 & 13182 & 0.2 & 13.1 \\
\hline Libya & 471 & 1010 & 5067 & 7.6 & 20.2 \\
\hline Malaysia & 1385 & 17237 & 131762 & 25.2 & 25.4 \\
\hline Singapore & 776 & 11095 & 56581 & 26.6 & 20.4 \\
\hline S. Korea & 524 & 990 & 1521 & 6.4 & 5.4 \\
\hline Brunei & 910 & 1420 & 1054 & 4.4 & -3.7 \\
\hline
\end{tabular}

Table 3: Employment of Bangladesh engaged in the world and \begin{tabular}{ll} 
Malaysia & \\
\hline Total Employment Malaysia \% of Malaysia of
\end{tabular}

Year involved in the world (employment) total employment

\begin{tabular}{lrrr}
\hline 1990 & 103814 & 1385 & 1.3 \\
1991 & 147131 & 1628 & 1.1 \\
1992 & 188124 & 10537 & 5.6 \\
1993 & 244508 & 67938 & 27.8 \\
1994 & 186326 & 47826 & 25.7 \\
1995 & 187543 & 35174 & 18.8 \\
1996 & 211714 & 66631 & 31.5 \\
1997 & 231077 & 2844 & 1.2 \\
1998 & 267667 & 551 & 0.2 \\
1999 & 268182 & 918 & 0.3 \\
2000 & 222686 & 17237 & 7.7 \\
2001 & 188965 & 4921 & 2.6 \\
2002 & 225256 & 85 & 0.0 \\
2003 & 254190 & 28 & 0.0 \\
2004 & 272958 & 224 & 0.1 \\
2005 & 252702 & 2911 & 1.2 \\
2006 & 381516 & 20469 & 5.4 \\
2007 & 832609 & 273201 & 32.8 \\
2008 & 875055 & 131762 & 15.1 \\
Total & 6265909 & 686270 & 1.0 \\
\hline
\end{tabular}

Source: Modify from Bureau of manpower, Employment and Training (BMET)

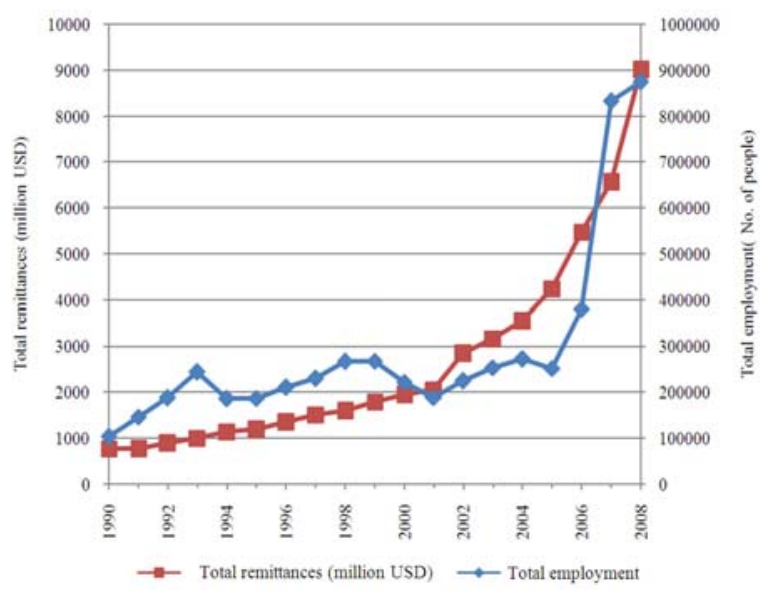

Fig. 1: Total employment and remittances 
Am. J. Environ. Sci., 7 (1): 20-25, 2011

\section{CONCLUSION}

International migration and remittances have a strong, significant impact on reducing poverty in developing country like Bangladesh. In Bangladesh international migration and remittances are increasing, it has a significant impact on poverty reduction. Bangladesh still receives lower amount of remittances compare to the other developing country. Compared to the other labour sending countries number of Bangladesh immigrants is smaller, mostly short term in employment, less skilled in working performance and low paid. Informal remittance transfer has long been seen as a strong barrier to receiving remittances in full swing. With respect to migration, the positive impact of international migration on poverty makes the policy question of "managing migration" assume greater importance in the international development community. While the international community has paid considerable attention in past to international movements of goods, services and finance, much less attention has been paid to the international movements of people.

\section{ACKNOWLEDGEMENT}

Financial assistance provided by the Grant University Project (GUP), Institute for Environment and Development, University Kebangsaan Malaysia is gratefully acknowledged.

\section{REFERENCES}

Azad, A.K, 2005. Migrant Workers' Remittances: A Source of Finance for Micro-Enterprise Development in Bangladesh? In Remittances: Development Impact and Future Prospects, Maimbo, S.M. and D. Ratha, (Eds.). World Bank Publication, Washington D.C. pp: 119-132.

Ministry of Finance, 2003. Bangladesh Economic Review. Economic Adviser's Wing Finance Division, Ministry of Finance, Bangladesh, pp: 31.

Castles, S. and R.D. Wise, 2008. Migration and Development: Perspectives from the South. 1st Edn., International Organization for Migration, Geneva, ISBN-10 9290684178, pp: 314.

Castles, S., 2007. Twenty-first-century migration as a challenge to sociology. J. Ethnic Migration Stud., 33: 351-371. DOI: 10.1080/13691830701234491

Gammeltoft, P., 2002. Remittances and other financial flows to developing countries. Int. Migration, 40: 181-211. DOI: 10.1111/1468-2435.00216

Harvey, P., 2007. Remittances During Crises: Implications for Humanitarian Response. 1st Edn., HPG, Overseas Development Institute, England, ISBN-10: 0850038464, pp: 48.
IMF, 2005. Bangladesh: Poverty Reduction Strategy Study. International Monetary Fund Washington, D.C.

Internal Resources Division, 2005. Ministry of Finance. Government of Bangladesh.

Adams, Jr., R.H. and J. Page, 2003. The Impact of International Migration and Remittances on poverty. World Bank.

Keely, C.B. and B.N. Tran, 1989. Remittances from labour migration: Evaluations, performance and implications. Int. Mig. Rev., 23: 500-525. PMID: 12282791

Maimbo, S.M.. and D. Ratha, 2005. Remittances: Development Impact and Future Prospects. 1st Edn., The World Bank Publications, Washington D.C., ISBN-10: 0821357948, pp: 378.

Morawska, E., 2001. Structuring migration: The case of polish income-seeking travelers to the west. Theory Soc., 30: 47-80. DOI: 10.1023/A:1011081228016

Nasiruddin, A. and N.K. Das, 2007. Making Bangladesh a leading exporter of human resources. Ministry of Finance, Government of Bangladesh.

OECD, 2007. International Migration Outlook. 1st Edn., Organization for Economic Co-operation and Development Publications, Paris, ISBN-10: 9264032851, pp: 329.

Puri, S. and T. Ritzema, 1999. Migrant Worker Remittances, Micro-Finance and the Informal Economy: Prospects and Issues. 1st Edn., ILO, Geneva, ISBN-10: 9221117839, pp: 33.

Ratha, D., 2003. Workers' Remittances: An important and Stable Source of External Development Finance. World Bank Publication.

Ravallion, M. and S. Chen, 1997. What can new survey data tell us about recent changes in distribution and poverty? World Bank Econ. Rev., 11: 357-382. DOI: $10.1093 /$ wber/11.2.357

Richard, H.A.J., 2006 Remittances and poverty in Ghana. Social Science Electronic Publishing, Inc.

Shahamak, R., 2010. Cross European financial networks related to Turkish immigrants and their businesses: the case of Turkish-owned commercial bank under dutch legislation. Am. J. Econ. Bus. Admin., 2: 253-265. $\quad$ DOI: 10.3844/ajebasp.2010.253.265

Stanat, P. and G. Christensen, 2006. Where Immigrant Students Succeed: A Comparative Review of Performance and Engagement in PISA. 1st Edn., OECD Publishing, Paris, ISBN-10: 9264023607, pp: 222. 
Am. J. Environ. Sci., 7 (1): 20-25, 2011

The World Bank, 2005. Global Economic Prospects. 1st Edn., The World Bank, Washington D.C., ISBN10: 0821363441, pp: 182.
World Bank, 2010. Migration and Remittances Factbook 2010. 1st Edn. The World Bank, Washington D.C., ISBN-10: 0821382187, pp: 256. 